Vol. 12 (2003): 3-19.

\title{
EU enlargement and the Common Agricultural Policy: The case of Slovenia
}

\author{
Stane Kavcic, Emil Erjavec \\ University of Ljubljana, Biotechnical Faculty, Chair for Agricultural Policy, Groblje 3, \\ SLO-1230 Domzale, Slovenia,e-mail: stane.kavcic@bfro.uni-lj.si \\ George Mergos and Chrisostomos Stoforos \\ University of Athens, Department of Economics, Athens, Greece
}

\begin{abstract}
The paper aims at assessing the economic effects of Slovenia's accession to the EU. For this purpose, a sector model of Slovenian agriculture APAS-PAM has been constructed. The methodological framework allows for assessment of market, income and competitiveness effects for ten key agricultural products with consideration of two accession scenarios (optimistic EUe and pessimistic EUp) that describe the whole range of possible accession effects. Slovenia's accession to the EU will not increase agricultural production significantly. Accession under the scenario of complete acceptance of the CAP mechanisms and quasi equal treatment by the EU (EUe) will not bring significant changes to aggregate production and income levels with moderate changes on commodity basis. Discrimination of the candidate countries in the field of direct payments and non-competitive down-stream sector assumed by the EUp- subscenario will significantly deteriorate the income situation of domestic producers. This holds especially for cereal and beef production. For many commodities, the competitiveness of the food processing industry assuming different price levels for raw materials could have much greater impact on the economic situation of agricultural production than agricultural policy environment itself.
\end{abstract}

Key words: agricultural policy, CAP, European Union, EU enlargement, supply response, income, costs, Slovenia

\section{Introduction}

The next European Union (EU) enlargement will have multiple impacts on CEECs (Central and Eastern European Countries) agriculture (Baldwin et al. 1997). As previous enlargement shows, farmers will have to adjust their quantities supplied, shift products and modernise in order to be competitive. Price movements due to harmonisation will probably change cost competitiveness of production and influence trade balance. Moreover, even small price variations and minor modifications in budgetary support may dra- 
Kavcic, S. et al. EU enlargement and the Common Agricultural Policy

matically change the level of income earned by producers on both sides (in "old" and "new" member states), which can, in the end, lengthen the integration process for new member states. Assessment of market and income effects has been a subject of numerous studies (Banse 2000, Münch 2000, European Commission 2002a). Their common message is that enlargement and full adoption of Common Agricultural Policy (CAP) measures by the candidate countries would lead in most of them to increased production levels and improved income position of agriculture.

The conclusions of the Berlin summit of March 1999 and the European Commission negotiation strategy of 30 January 2002 clearly defined the financial framework of EU enlargement in the area of agricultural policy. The figures reveal that the newly-coming member states will not be fully participating in CAP direct payments. The reason lies on lower current price levels as well as potentially negative social and macroeconomic effects in candidate countries. In addition, higher prices are expected to be a stimulus to growth of agricultural production in the new members, and this could consequently create serious additional budget pressures on CAP. The same argumentation for a two-tier agricultural policy after EU enlargement is also expressed by Pouliquen (2001). Therefore, it is clear that the issue concerning direct payments is on top of the political agenda in the negotiating process of the next EU enlargement.

There are some reports that agriculture in Slovenia should be treated differently than that in other CEECs (European Commission 1995, Bojnec and Swinnen 1997, European Commission 1998, Erjavec et al. 1998a, OECD 2001a). The significance of the agricultural sector in Slovenia is relatively small, accounting for around $3.5 \%$ of gross domestic product (GDP) and $6 \%$ of total employment after transition, with a further decreasing rate over the last four years. Contrary to other candidate countries, producer prices in Slovenia are almost at the EU level of prices and due to the natural and structural conditions, Slovenia is a net importer of food, with a smaller potential for production growth. Private-owned land is mostly divided between 86,000 small, mainly part-time family farms (Agricultural census 2000 data, according to Eurostat definition) with an average farm size of 5.2 ha utilised agricultural area (UAA). Few agricultural enterprises have evolved from the formerly "social" agricultural estates.

The level of support for agriculture in Slovenia is significantly higher than in any other CEEC country. Producer support estimates (PSE) by OECD (2001a) show that for the whole period of 1992-1999 Slovenian producers were subsidised. It is apparent that market price support represented more than $80 \%$ of total agricultural support. In 1995-1999, average percentage PSE in Slovenia $(41 \%)$ was above the OECD level $(35 \%)$ and nearly the same as in EU (42\%). The high PSE levels in Slovenia reflect substantial domestic price support and border protection for the most important agricultural commodities (milk products, beef, and pig meat), as well as steadily growing budgetary transfers to producers. In addition, the Slovenian agricultural policy framework (objectives and measures) is already close to that of the CAP. Direct payments and intervention mechanisms (but not quotas), introduced by the 2000-2002 agricultural policy reform, aim to adjust domestic policy to such a degree that accession will not yield dramatic modifications for producers.

The objective of this paper is to contribute to the discussion on EU enlargement with the estimation of the possible impacts (market trends, agricultural income and cost competitiveness of production) for the agricultural sector in Slovenia by the use of relevant empirical tools. In this way, it is tested whether Slovenian agricultural sector actually depends on the level of EU direct aids after accession and if it is justified to apply the same policy for all candidate countries despite the changes among them. The paper is structured as follows: first, the empirical framework and two policy scenarios under which Slovenia could evolved after accession are described. Second, market projections and resulting trade flows start the presentation of the model 
Vol. 12 (2003): 3-19.

results. Further on, trends in agricultural income and the competitiveness dimension of the accession are presented. Finally, the paper concludes with policy evaluation and some policy recommendations.

\section{Methodology}

\section{APAS - PAM model}

There are two main modelling approaches for policy analysis: the partial equilibrium and the general equilibrium approaches, with different levels of theoretical consistency and econometric pre-evaluation of the elasticities (Bauer 1989, Burrell 1995, Salvatici et al. 2000). In the literature, multi-commodity partial equilibrium econometric models are still the basic tool for agricultural policy analyses (Tongeren et al. 2000). The models have different levels of theoretical consistency, with parameters being mainly estimated and calibrated during model testing. The advantage of a multi-market model in analysing agricultural price and trade policies is that it can accommodate a large number of products (in our case livestock, food and feed crop products) that represent significant share of total agricultural production. This approach has been followed also during building of agricultural policy analysis simulation model (APAS) used in this study. This model is a modification of an earlier one developed by Mergos (1988), Stoforos (1997), Mergos et al. (1999) and Stoforos et al. (2000).

This analysis is based on a synthetic-type, multi-market, partial equilibrium model together with a policy analysis matrix (PAM) to explore agricultural price and trade policy options in Slovenia. The APAS is designed as a national sector model, taking into account the specific features of Slovenian agro-industry and recent policy changes (Kavcic 2000). It is primarily focused on market projections. On the other hand, PAM has been used for analysing income, protection and competitive issues for the same policy scenarios.

The model includes all most important agricultural "PSE commodities" (arable crops: wheat and maize, barley and sugar beet; livestock products: milk, beef, pork and poultry, eggs and sheep meat). Together these commodities account for approx. $80 \%$ of Slovenian gross agricultural output.

\section{Framework for market projections}

APAS, as a policy-oriented simulation model, normally examines relationships within the agricultural sector and not resource shifts between sectors. Factor prices and other general equilibrium conditions are assumed to be fixed, although some macro elements enter the model in the form of various policy scenarios (partial equilibrium elements). Model parameters are not estimated with APAS framework; rather, they are obtained from the literature or can be econometric estimates. However, theoretically valid behavioural relationships can be and were imposed on the supply and demand elasticities actually used (synthetic approach). The model is designed to analyse the economic implications of policy changes that can have an important impact (policy orientation).

The core of the model consists of a set of elasticity matrices - a matrix of demand elasticities and a matrix of supply elasticities. The solution adopted for the determination of the functional form of the equations used in the model was the calibration of the model using elasticities from previous estimations for Slovenian agriculture (Erjavec and Turk 1997, Erjavec et al. 1998b) and literature (Gardiner et al. 1989). They used single equation supply functions (the same occurred for the demand elasticities) with the imposition of homogeneity using the strong separability assumption.

The model simulates the impact of changes in a set of exogenous variables and government policies on a set of endogenous variables. The model starts from a base year 1999/2000 (the 
Kavcic, S. et al. EU enlargement and the Common Agricultural Policy

latest year for which coherent data set is available) and then projects the changes that result from the implementation of various scenarios.

The credibility of a model is tested every time the model is used for policy analysis by ensuring some calibration of the model for the base year. This is provided by adjusting the constant terms in a set of supply and demand equations. Also the logical structure of the model is checked for internal consistency and conceptual validity. In addition, the model's predictive ability in a real world situation is tested by running the model against situations with time-series data that are available, i.e. using historic simulation.

In this form of the model there are 4 equations for each product: (i) land used or total number of animals; (ii) yield; (iii) total supply (this is based on an identity i.e. (i)*(ii)) and (iv) demand.

The general form of the area equations used in the model is:

$\ln L_{i}=A_{i}+\sum_{y=1}^{n}\left(\varepsilon_{i y}^{L} \times \ln \frac{P I_{y}}{P_{c}}\right)+B_{i} \times \ln L_{i 0}$

where $L_{i}$ is the cultivated area (or the number of animals) of product i, $A_{i}$ the constant term (for the base year), $P I_{y}$ 's are incentive prices (taking into account budgetary support as well as input prices to reflect gross returns), $P_{c}$ is the consumption deflator, $L_{i 0}$ base year area of product i, $B_{i}$ the short run trend and $\varepsilon_{i y}^{L}$ the corresponding own and cross price (area) elasticities. It is important to point out that the area equations are solved simultaneously under the restriction of total land availability,

$\sum_{y=1}^{n} L_{i} \leq$ land available [ha]

where only crops are taken into account.

The general form of the yield equation used in the model is:

$\ln Y_{i}=G_{i}+\sum_{y=1}^{n}\left(\varepsilon_{i y}^{Y} \times \ln \frac{P_{y}}{P_{c}}\right)+\Gamma_{i} \times \ln Y_{i 0}$

where $Y_{i}$ is the yield of product i, $G_{i}$ the constant term (base year), $P_{y}$ 's are corresponding own or cross prices, $Y_{i 0}$ is the base year yield, $\Gamma_{i}$ coeffi- cient that corresponds to technological changes and $\varepsilon_{i y}^{Y}$ own and cross price (yield) elasticities. Zeros have been entered for most of the yield elasticities since yield in Slovenia is not very responsive to changes in price and it can be considered as a technology driven variable (the structure of production in Slovenian agriculture restricts the form and the value of yield elasticites). Non-zero elasticity values are insignificant in the analysis which concentrate on immediate effects. Hence it is assumed that yields are not affected by price changes or changes in direct subsidies, but it is the changes in gross returns of different products which matters. For purposes of policy analysis and for getting information related only to price changes, the same policy scenarios were run with and without technological changes.

Own price, cross price and income are the main explanatory variables in demand equations. The general form of the demand equations is as follows:

$$
\begin{aligned}
\ln D_{i} & =C_{i}+\sum_{y=1}^{n}\left(\varepsilon_{i y}^{D} \times \ln \frac{P D_{y}}{P_{c}}\right) \\
& +\eta_{i} \times \ln \frac{I}{P_{c}}+\Phi_{i} \times \ln D_{i 0}
\end{aligned}
$$

where $D_{i}$ is demand for product i, $C_{i}$ the constant term (base year), $P D_{y}$ 's are corresponding demand prices, $D_{i 0}$ is the base year demand for product I, $\Phi_{i}$ trend in consumer preferences, $\varepsilon_{i y}^{D}$ own and cross price demand elasticities, $\eta_{i}$ income elasticity of demand and $I$ income.

Prices in the model are determined by two major exogenous forces: the world market and/ or the government policies. These prices, in turn, determine the demand and supply of agricultural products. Trade is the equilibrating mechanism for balancing demand and supply of commodities given a certain set of prices (small country assumptions). Depending on the size and efficiency of the market in question, a country's domestic price is generally only a few percentage points above the border price for imports, and a few percentage points bellow the border price of exports. The existence of government price and trade policies with taxes and subsidies 
Vol. 12 (2003): 3-19.

on imports and/or exports can, however, drastically change the domestic-world market price spread.

The production decisions of farmers mostly depend on the real net income received relative to the costs of production. The real net output price received by farmers depends on the world market price, tariff and non-tariff barriers to trade, the real exchange rate, product and trade taxes, marketing costs and the rate of inflation as measured by the consumer price index. The costs of production depend, among other factors, on the prices of input factors and, if available, government subsidies.

In order to determine model prices used for policy analysis and projections, a transmission equation was used, so that world prices could enter the domestic market adjusted according to the implementation of various border policies (taxes or subsidies).

$$
\begin{aligned}
& M P_{i}=\left(B P_{i} \times X R\right) /\left(B P_{i} / X P_{i}\right) \\
& B P_{i}=V a X_{i} / V_{0} X_{i} \text { or } B P_{i}=V a I_{i} / V I_{i} \\
& X P_{i}=D P_{i} \times X R \\
& D P_{i}=\operatorname{PrP}_{i}+A_{i} \times \Pi_{i}
\end{aligned}
$$

where $M P$ is the price used in the APAS and PAM model for policy analysis and forecasting, $B P$ is the border price determined by value and volume ( $V a$ and $V o$ ) of exports (X) for the exporting products and of imports (I) for the importing products, $X R$ is the USD or EUR exchange rate, $X P$ is the domestic price expressed in foreign currency, $D P$ is the domestic price expressed in SIT (Slovenian currency), $\operatorname{Pr} P$ is the producer price, $A$ is a policy multiplier and $\Pi$ is the policy (measure) affecting farmer's decision making.

Equation $5 \mathrm{c}$ introduces the various domestic or EU policies, such as direct payments for cereals, animal premiums or policies that can be quantified and assumed to affect producer's decisions for increasing or decreasing their production. The basic assumption of this model is that through a multiplier effect $(A)$ policies are introduced into the price system (Frohberg 1999, Stoforos et al. 2000) and determine the production and consumption levels. Other policies, like quantity or land restrictions (i.e. sugar, milk) are introduced via the maximization process where the quota level is imputed as the restriction to the output (quota levels are determined in different levels among the various scenarios).

\section{Measuring income and competitive impacts}

APAS is used along with a policy analysis matrix. PAM model has been selected as a basic technique for analysing income, protection and competitive issues of different policy options. The reason underlying this decision is in its relative simplicity, data availability and straightforward procedure of calculations. The basic PAM methodology has been developed in USA (Monke and Pearson 1989) and widely used in many developing countries (Goldman et al. 1991, Harrigan et al. 1992, Pearson et al. 1995 Kydd et al. 1997, Yao 1997a). It has also been used for estimation of likely consequences of full membership of Portugal in EU on its agriculture (Pearson et al. 1987) and more recently for the same purpose in Estonia (Yao 1997b) and Slovak Republic (Michalek 1995). For more detailed literature review see Kavcic (2000).

The PAM provides a systematic framework for assessing the impacts of government's intervention in certain production systems. According to Monke and Pearson (1989) the structure of PAM can be described as a product of two accounting identities. The first one defines profit as the difference between revenues and costs, while another one measures the effects of divergence (distorting policies and market failures) as the difference between observed parameters and parameters that would exist if the divergences were removed. By completing a PAM for a production system one can simultaneously determine the existing economic efficiency of the system, the degree of distortion on the input/ 
Kavcic, S. et al. EU enlargement and the Common Agricultural Policy

Table 1. Structure of Policy Analysis Matrix (Monke and Pearson 1989).

\begin{tabular}{lcccc}
\hline & Revenues & Tradable input costs & Domestic resource costs & Profits \\
\hline Private values & A & B & C & D \\
Social values & E & F & G & H \\
Divergence & I & J & K & L \\
\hline
\end{tabular}

Private profit, $\mathrm{D}=(\mathrm{A}-\mathrm{B}-\mathrm{C})$; Social profit, $\mathrm{H}=\mathrm{E}-\mathrm{F}-\mathrm{G}$; Output transfers, $\mathrm{I}=\mathrm{A}-\mathrm{E}$; Tradable input transfers, $\mathrm{J}=\mathrm{B}-\mathrm{F}$; Non-tradable input transfers, $\mathrm{K}=\mathrm{C}-\mathrm{G}$; Net transfer, $\mathrm{L}=\mathrm{D}-\mathrm{H}=\mathrm{I}-$ $\mathrm{J}-\mathrm{K}$.

output markets, and the extent to which resources are transferred among agents.

The two distinct characteristics of PAM are the classification or disaggregation of the costs of inputs into their tradable and non-tradable components and the valuation of revenues, costs and benefits using both market (private) and efficiency (social, shadow or economic) prices. Tradable inputs include those inputs that can be traded in the world market (fertilisers, seeds, pesticides). The non-tradable inputs are mainly domestic factors which are not traded internationally (land, labour, local capital). Most inputs, however, come in as a mixture of some tradable and non-tradable components and must be disaggregated into their respective tradable and nontradable components. A summary of the PAM approach is given in Table 1 .

The valuation of revenues, costs and profits by their private and social prices allows PAM to determine the extent of divergences caused by policy intervention and/or market failure in both the input and output markets. In this context the private prices are simply the open market prices and the social prices are the shadow prices of all the inputs and outputs of the concerned production system. For tradable goods their shadow prices are the (export or import) parity prices, evaluated with world price (c.i.f. or f.o.b.) at the point of utilisation. The same principle applies to output. For non-tradable factors their shadow prices are the values of output forgone of their best alternative use, i.e. the opportunity costs of the factors.

Private profit is defined as the difference between the value of output produced $\left(p_{o}^{*} q_{o}^{*}\right)$ and of inputs used $\left(p_{i}^{*} q_{i}^{*}\right)$ valued at vectors of market (private) prices as follows (Khan 1997):

$$
\Pi_{o}^{*}=p_{o}^{*} q_{o}^{*}+p_{i}^{*} q_{i}^{*}
$$

In the same way economic or social profitability can be defined as the difference between value of outputs produced $\left(p_{o} q_{o}\right)$ and of inputs used $\left(p_{i} q_{i}\right)$ priced at their social opportunity costs as follows:

$\Pi_{o}=p_{o} q_{o}+p_{i} q_{i}$

Private profit measures the private profitability faced by the producer for the production of a certain product. Social profit is a measure of social profitability. Because private and social prices may be (and in most cases are) different, social profitability does not coincide with private profitability. A crop which is socially profitable can be unprofitable to a private producer if the private price offered is lower because of a taxation in the production process. Similarly, a certain crop which is privately profitable to a producer can involve a net loss to the society if its production is subsidised.

Output transfer measures the divergence between the private and social revenue. Therefore, it reflects the extent to which the product market is distorted by government policy. Tradable input transfer and non-tradable input transfer are divergences between the private and social values of inputs and so measure the transfer (taxation or subsidy) from the producers to the society for their purchase. Net transfer measures the extent of distortion in profitability. It reflects the 
Vol. 12 (2003): 3-19.

net effects of distortions occurring in both the input and output markets.

All measures previously described provide important information on the extent of profitability and distortions faced by production systems, but being absolute figures they cannot be used for comparisons among different systems of production or across countries. To overcome this problem, PAM provides a set of relative indicators like well-known nominal protection coefficient on outputs (NPC), the effective protection coefficient (EPC) and the domestic resource cost ratio (DRC).

$N P C=\frac{p_{o}^{*}}{p_{o}} \mathrm{EPC}=\frac{p_{o}^{*} q_{o}^{*}-p_{t}^{*} q_{t}^{*}}{p_{o} q_{o}-p_{t} q_{t}}$

NPC is defined as ratio of domestic market price $\left(\mathrm{p}^{*}\right)$ to the border parity price ( $\mathrm{p}$ ) of a commodity. In the PAM framework, this is equal to the ratio of private revenue to social revenue. It is a summary indicator of all government's intervention preventing equality between domestic price and border parity price of a commodity. NPC > 1 indicates implicit subsidy of domestic production. NPC considers distortion of government policy in product market. EPC as ratio of value-added measured at private prices to value-added at social prices, measures the total effects of intervention in both markets. If EPC $>1$, it implies that overall impact of the existing policy results in a net positive incentive to produce the commodity.

DRC is the ratio of domestic factor cost required to produce a certain amount of output valued at social prices to the value-added created by the same resources at social prices. Therefore, it is a social cost-benefit ratio, which helps determine the desirability of certain domestic production system relative to the international market in terms of economic efficiency.

$\mathrm{DRC}=\frac{p_{n} q_{n}}{p_{o} q_{o}-p_{t} q_{t}}=1-\frac{N S P}{p_{o} q_{o}-p_{t} q_{t}}$ where

$N S P=p_{o} q_{o}-p_{t} q_{t}-p_{n} q_{n}$ and $o$ depicts output, $t$ tradable costs and $n$ nontradable costs of producing certain amount of commodity under investigation.

The domestic factor cost is the opportunity cost of domestic resources involved in the production of commodity and the benefit is the value-added generated by the resources measured at social prices. If the cost is greater than benefit, production of commodity is not desirable from the social point of view. At DRC $<1$ domestic factor cost is less than social benefit generated by resources involved, what implies that it is socially desirable to expand the production of the concerned commodity (Yao 1997a). Assuming no distortion in the world market it also implies comparative advantage of the country in producing the commodity. Contrary DRC $>1$ implies that the country is not competitive internationally in the production of the commodity, since the opportunity cost of the domestic factors involved in the production of the concerned commodity is greater than the social value-added generated by those factors. As an important indicator of comparative advantage, DRC can be used to rank the competitiveness of different commodities.

Through APAS projections for yield, land (or herd) and output for every product under consideration it is possible, as it was pointed previously, to incorporate all relevant information to the PAM model so as to get valuable information for protection, competitiveness and income for all policy scenarios.

Income was estimated for each activity using the following equation:

$$
\begin{aligned}
N I_{i} & =V P_{i}-I C_{i}+S b_{i}-T x_{i}-D p_{i}-R n_{i} \\
& -I n t-W g
\end{aligned}
$$

where $N I$ stands for net income, $V P$ is value of (crop or livestock) production, IC is intermediate consumption, $S b$ are subsidies, $T x$ taxes, $D p$ depreciation, $R n$ rents, Int interests and $W g$ wages of hired labour.

Net income was calculated per hectare of land for crop production and per head for livestock production as well as at aggregate level, apply- 
Kavcic, S. et al. EU enlargement and the Common Agricultural Policy

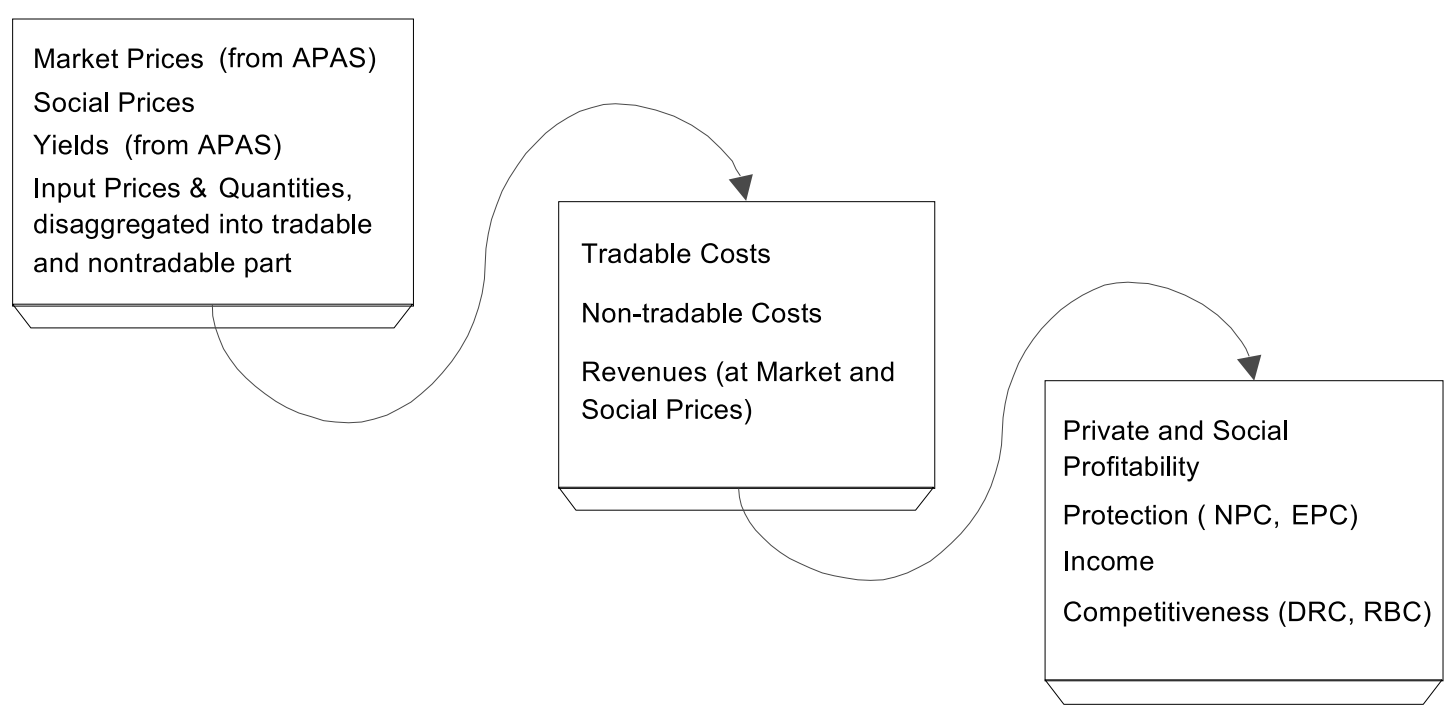

Fig. 1. Policy Analysis Matrix model data flow. APAS = agricultural policy analysis simulator, NPC = nominal protection coefficient, $\mathrm{EPC}=$ effective protection coefficient, $\mathrm{DRC}=$ domestic resource cost ratio, $\mathrm{RBC}=$ rate of bilateral competitiveness.

ing size of production (acreage or number of animals) previously calculated by APAS. The same holds for yields, which are incorporated to PAM from APAS projections and results obtained were applied in PAM analysis both to revenue side and to input (cost) side. Yields' improvements are a consequence of technological changes implying different input levels, which were calculated using linear regression procedure (assuming marginal costs of different cost items to be constant on a range of average yields' changes). PAM procedure, followed in this study, is summarised in Figure 1.

The newest version of APAS-PAM model provides the possibility for calculation both DRC and RBC (domestic resource cost ratio and rate of bilateral competitiveness) indicators of competitiveness. The later one refers to the ability of producers to be profitable when faced with investigated economic environment. In our instance that means baseline or policy scenario of assumed EU market and tradable input prices, with the costs of the factors of production measured in terms of their opportunity costs (for more detailed explanation see Gorton and Davidova 2000).
A static model like PAM in its original form may generate results that are not realistic in a dynamic sense and potentially biased against government policies. To overcome this limitation, a connection was established between PAM and APAS to identify likely changes of private profitability in mid term, i.e. if Slovenia would adapt its agricultural policy to reformed CAP under various policy scenarios. For this reason, all parameters already mentioned have been calculated for base year (1999/2000) as well as for years 2004-2010.

Original PAM analysis assumes fixed inputoutput coefficients to determine the relative economic efficiency and uses fixed levels of macroeconomic variables (e.g. exchange rate). This implies that PAM results are for the base year and cannot be used to recalculate the new quantities of output and inputs that would result from general equilibrium effects due to changes in social opportunity costs or change in other variables. Another general assumption is that PAM does not link different activities endogenously and implies that changes in the profitability of one farm activity will not alter the input-output relationship in other activities or even the level 
Vol. 12 (2003): 3-19.

of inputs into other activities. Such general equilibrium effects are not captured by PAM directly because PAM does not include elasticity estimates (Khan 1997). Part of these limitations can be minimised by relaxing assumptions that are made to estimate some key parameters. Usually this is conducted by sensitivity analysis to assess the robustness of PAM results to changes in parameter assumptions. In our study another approach has been selected, namely linkages with a partial equilibrium model (APAS) that incorporates elasticity estimates. Such approach gave the possibility to estimate impacts of changes, projected in the next decade. Furthermore, along with market prices and budgetary payments, deviations in input costs (material costs and depreciation) have been used as correction factors for determination of policy scenarios' incentive prices.

\section{Scenarios and data}

The simulation was run using baseline and two policy scenarios. The latter present the possible effects of the Commission proposal (European Commission 2002b) on the Slovenian agriculture after accession.

- Baseline scenario (BS). It assumes continuation of agricultural policy from 1999/2000 and predominantly serves as a comparison tool. It takes into consideration intermediate policy changes, deriving from trade agreements. Like for the policy scenarios, the anticipated price movements are derived from the agricultural outlook for different regions (OECD 2001b, FAPRI 2001).

\section{- Quasi Equal treatment scenario (EUe).} This scenario assumes that the candidate countries will apply the same CAP as current member states with the full level of direct payments at the date of EU enlargement (i.e. in 2004 as the assumed accession and also as the simulated year). Two versions of this scenario are a subject of this study. The first one assumes competitive domestic food processing industry (EUe+) contrary to the scenario of non-competitive processing industry (EUe-), reflected in lower producer prices (Table 2).

- EU negotiating proposal scenario (EUp). The accession scenario for candidates (i.e. Slovenia) as proposed by European Commission in its negotiating strategy of 30 January 2002 (European Commission 2002b). It assumes direct payments amounting to $25 \%$ of the current member states' level and complemented up to the pre-accession (baseline) level (toping-up approach), the given proportion of rural development programmes $(2.1 \%$ of payments for candidate countries from EAGGF-Guarantee Section). Again, the first set of simulation results refer to relatively high level of producer prices (EUp+) and the second one to reduced producer prices (EUp-). The reason behind this distinction is the same as for EUe scenario.

Assumed as accession is the period from 2004 onwards, with the full absorption capacity for the CAP measures starting in the same year. 2004 is also the period observed in the model since immediate impacts of EU accession are at the top of policy interest.

The price levels determined for the various scenarios have considerable influence on all indicators of interest (Table 2).

The relevant data for the analysis were provided by the Agricultural Institute of Slovenia (Volk 2001a, b, Golez 2001) and various published or recalculated sources of the Statistical Office of the Republic of Slovenia.

\section{Results}

Model results reported in this chapter refer to simulated year 2004. Results obtained for nominal protection are summarised in Table 3.

Excluding maize production, all products under investigation are highly protected, with NPC mostly between 1.5 and 1.75. The EU ac- 
Kavcic, S. et al. EU enlargement and the Common Agricultural Policy

Table 2. Scenario assumptions - producer prices in Slovenia and in "comparable" EU markets, 2000 and projection for 2004.

\begin{tabular}{lrrrrrrrrrr}
\hline Scenario (and year) & Wheat & Maize & Barley & $\begin{array}{c}\text { Sugar } \\
\text { beet }\end{array}$ & Milk & Beef & Pork & Poultry & Eggs & $\begin{array}{r}\text { Sheep } \\
\text { meat }\end{array}$ \\
\hline SLO 2000 (EUR t-1) & 138 & 114 & 117 & 31 & 290 & 2507 & 1491 & 1048 & 1207 & 4045 \\
EU 2000 (EUR t ${ }^{-1}$ ) & 107 & 120 & 100 & 46 & 283 & 2546 & 1271 & 923 & 808 & 3341 \\
Index SLO/EU & 129 & 95 & 117 & 68 & 102 & 98 & 117 & 113 & 149 & 121 \\
EU.- deviation from EU.+ (\%) & -15 & -5 & -5 & -5 & -15 & -10 & -10 & -20 & -35 & -15 \\
& & & & & & & & & & \\
BS 2004 (EUR t ${ }^{-1}$ ) & 143 & 118 & 119 & 32 & 299 & 2131 & 1336 & 950 & 1073 & 4170 \\
EU.+ (BS = 100) & 82 & 103 & 93 & 122 & 98 & 93 & 94 & 97 & 84 & 83 \\
EU.- (BS = 100) & 70 & 98 & 88 & 116 & 83 & 83 & 84 & 78 & 54 & 70 \\
\hline
\end{tabular}

Sources: Statistical Office of the Republic of Slovenia, Agricultural Institute of Slovenia, Eurostat, FAPRI 2001, OECD 2001b, model assumptions

$\mathrm{BS}=$ baseline scenario

EU.+ and EU.- = scenarios of EU accession, with + or - depicting producer price level, depending on assumed competitiveness of processing industry

Table 3. Forecasted nominal protection coefficient on outputs ratios for commodities investigated.

\begin{tabular}{lcccccccccc}
\hline & Wheat & Maize & Barley & Sugar beet & Milk & Beef & Pork & Poultry & Eggs & Sheep meat \\
\hline BS & 1.57 & 1.06 & 1.26 & 2.39 & 1.74 & 1.64 & 1.55 & 1.18 & 1.56 & 1.72 \\
EUe+ & 1.71 & 1.65 & 1.68 & 2.26 & 1.76 & 2.09 & 1.02 & 1.18 & 1.19 & 2.09 \\
EUe- & 1.87 & 1.71 & 1.75 & 2.26 & 1.75 & 2.19 & 1.03 & 1.18 & 1.20 & 2.45 \\
EUp+ & 1.57 & 1.26 & 1.35 & 2.21 & 1.70 & 1.61 & 0.99 & 1.17 & 1.18 & 1.71 \\
EUp- & 1.67 & 1.28 & 1.38 & 2.22 & 1.70 & 1.67 & 1.00 & 1.18 & 1.19 & 1.87 \\
\hline
\end{tabular}

$\mathrm{BS}=$ baseline scenario

$\mathrm{EUe}=$ quasy equal treatment scenario

$\mathrm{EUp}=\mathrm{EU}$ negotiating proposal scenario

cession will bring significant changes in the absolute values and also in the ranking. Pork is likely to become the least protected sector, followed by poultry and eggs. Sectors with direct payments will be more protected comparing to BS, or in case of lower price levels will remain at the comparable level. Sugar (beet) production will remain the most protected.

\section{Competitiveness}

Domestic resource cost ratio and the rate of bilateral competitiveness (RBC) was estimated for all products under consideration. Results obtained are presented in Table 4.
RBCs show relatively favourable competitive position of Slovenian agriculture in the event of non-discriminative EU agricultural policy environment (EUe+), conditioned upon (competitive) domestic food industry. Opposite is the case in a liberalised situation on agricultural markets (DRC above 1 or even negative, with no exemption). Differences between various commodities are obvious. Grains and cattle (dairy and beef) production under subsidised CAP regime seems to be more competitive than sugar beet, pork, poultry, eggs and sheep meat production. The reasons for this are mainly high direct payments and/or highly protected markets, resulting in high revenues in proportion to domestic opportunity costs. Coarse grain production (maize and bar- 
Vol. 12 (2003): 3-19.

Table 4. Domestic resource cost ratio (DRC) and the rate of bilateral competitiveness (RBC) ratios for products under investigation.

\begin{tabular}{|c|c|c|c|c|c|c|c|c|c|c|c|}
\hline & & Wheat & Maize & Barley & $\begin{array}{c}\text { Sugar } \\
\text { beet }\end{array}$ & Milk & Beef & Pork & Poultry & Eggs & $\begin{array}{l}\text { Sheep } \\
\text { meat }\end{array}$ \\
\hline \multirow[t]{5}{*}{ DRC } & BS & 1.46 & 1.28 & 1.46 & -3.79 & 1.71 & 4.88 & 3.48 & 1.21 & 3.22 & 2.93 \\
\hline & EUe+ & 1.74 & 1.76 & 1.91 & -6.86 & 1.71 & 3.71 & 1.07 & 1.39 & 1.78 & 2.88 \\
\hline & EUe- & 2.90 & 2.12 & 2.18 & -5.21 & 2.10 & 5.01 & 1.29 & 3.09 & 10.87 & 3.88 \\
\hline & EUp+ & 1.75 & 1.82 & 1.94 & -6.85 & 1.70 & 3.71 & 1.07 & 1.39 & 1.78 & 2.88 \\
\hline & EUp- & 2.91 & 2.22 & 2.21 & -5.21 & 2.09 & 5.01 & 1.29 & 3.09 & 10.87 & 3.88 \\
\hline \multirow[t]{5}{*}{$\mathrm{RBC}$} & BS & 0.60 & 1.12 & 0.98 & 1.37 & 0.75 & 1.12 & 1.02 & 0.73 & 0.82 & 1.09 \\
\hline & $\mathrm{EUe}+$ & 0.58 & 0.56 & 0.72 & 1.10 & 0.74 & 0.65 & 1.04 & 0.80 & 1.12 & 0.81 \\
\hline & $\mathrm{EUe}-$ & 0.64 & 0.57 & 0.73 & 1.23 & 0.87 & 0.68 & 1.23 & 1.29 & 3.02 & 0.77 \\
\hline & EUp+ & 0.67 & 0.98 & 1.06 & 1.15 & 0.77 & 1.03 & 1.11 & 0.82 & 1.15 & 1.09 \\
\hline & EUp- & 0.79 & 1.08 & 1.13 & 1.28 & 0.91 & 1.11 & 1.31 & 1.31 & 3.16 & 1.14 \\
\hline
\end{tabular}

$\mathrm{BS}=$ baseline scenario

EUe = quasy equal treatment scenario

EUp $=$ EU negotiating proposal scenario

ley) with relatively small direct payments (EUp) is unlikely to be competitive. The same holds also for sheep meat production. Pork, eggs and poultry production is far from being competitive under speculation of non-competitive domestic food industry. It is important to stress that EU accession - even under equal treatment scenario - would not significantly improve the competitiveness of great majority of investigated commodities. In cases where RBC ratio decreases under EUp in comparison with baseline (only maize and beef), it is a consequence of still high discrepancy between domestic agricultural policy and the current CAP. For many commodities, the competitiveness of the food processing industry with lower or higher prices for rough materials could have much greater impact on the economic situation of agricultural production than agricultural policy environment itself.

\section{Agricultural markets}

Mainly due to price and budgetary revenue disparities, assumed by both analysed accession scenarios, some significant changes on the sup- ply (and less on the demand) side can be predicted even in the short run (Table 5). Wheat, pork, poultry and eggs production would be affected most by the price reduction, while milk and, potentially, sugar beet production would be reduced due to quotas imposed. Due to price and cross price effects, coarse grain production is expected to remain almost at the baseline level. Only beef production is expected to increase significantly or - under least favourable conditions, which are more realistic - at least not drop.

Production of eggs, poultry, pork, milk as well as wheat will be very sensitive to price reduction (EU-scenario). Egg production could decrease by nearly a quarter. On the contrary, beef production is expected to increase. The extent of increase depends strongly on compensation eligibility (number and level of premium rights). On the demand side, wheat is expected to increase the most, predominantly due to price reduction effect, resulting in its increasing competitiveness as a feed component. On the other hand, demand for maize will be reduced mainly due to higher prices and reduced livestock production (pork, eggs, but also milk and poultry). 
Kavcic, S. et al. EU enlargement and the Common Agricultural Policy

Table 5. Projected supply (S) and demand (D) under various policy scenarios $(\mathrm{BS}=100)$.

\begin{tabular}{|c|c|c|c|c|c|c|c|c|c|c|c|}
\hline & & Wheat & Maize & Barley & Sugar & Milk & Beef & Pork & Poultry & Eggs & Sheep meat \\
\hline \multirow[t]{4}{*}{$\mathrm{S}$} & EUe+ & 96.1 & 106.7 & 103.4 & 105.2 & 98.2 & 114.4 & 97.1 & 99.0 & 92.8 & 101.0 \\
\hline & EUe- & 92.6 & 106.2 & 102.9 & 102.3 & 90.4 & 113.3 & 93.1 & 92.0 & 77.6 & 102.1 \\
\hline & EUp+ & 93.9 & 100.9 & 97.5 & 105.2 & 86.0 & 102.1 & 97.6 & 99.6 & 93.2 & 95.8 \\
\hline & EUp- & 88.9 & 99.7 & 96.2 & 102.4 & 86.0 & 100.3 & 93.7 & 92.6 & 78.1 & 93.4 \\
\hline & EU.+ & 102.7 & 98.8 & 100.7 & 98.8 & 100.3 & 101.1 & 100.4 & 100.0 & 101.6 & 102.0 \\
\hline & EU.- & 104.7 & 98.2 & 100.4 & 98.9 & 102.3 & 102.3 & 101.1 & 100.5 & 103.1 & 103.1 \\
\hline
\end{tabular}

$\mathrm{BS}=$ baseline scenario

EUe $=$ quasy equal treatment scenario

$\mathrm{EUp}=\mathrm{EU}$ negotiating proposal scenario

EU. $+=$ accession scenario of competitive processing industry

EU.- = accession scenario of non-competitive processing industry

Table 6. Expected levels of net trade (NT, $1000 \mathrm{t}$ ) and self-sufficiency (SS, \%).

\begin{tabular}{|c|c|c|c|c|c|c|c|c|c|c|c|}
\hline & & Wheat & Maize & Barley & Sugar & Milk & Beef & Pork & Poultry & Eggs & Sheep meat \\
\hline \multirow[t]{5}{*}{ NT } & BS & -170.7 & -145.9 & -85.3 & -20.3 & 91.3 & -2.5 & -28.3 & -0.7 & -1.8 & 0.0 \\
\hline & EUe+ & -186.7 & -115.8 & -84.4 & -16.9 & 80.4 & 3.3 & -30.3 & -1.3 & -3.6 & -0.1 \\
\hline & EUe- & -199.3 & -114.7 & -84.2 & -18.4 & 29.5 & 2.2 & -33.0 & -5.2 & -7.1 & -0.1 \\
\hline & EUp+ & -190.4 & -136.7 & -87.8 & -16.9 & 14.4 & -2.1 & -30.0 & -1.0 & -3.5 & -0.1 \\
\hline & EUp- & -205.7 & -137.8 & -88.0 & -18.3 & 5.5 & -3.4 & -32.7 & -4.8 & -7.1 & -0.2 \\
\hline \multirow[t]{5}{*}{ SS } & BS & 50 & 71 & 40 & 71 & 120 & 95 & 66 & 99 & 92 & 97 \\
\hline & EUe+ & 47 & 77 & 41 & 75 & 118 & 107 & 64 & 98 & 84 & 96 \\
\hline & EUe- & 44 & 77 & 41 & 73 & 106 & 105 & 61 & 90 & 69 & 96 \\
\hline & EUp+ & 46 & 72 & 39 & 75 & 103 & 95 & 64 & 98 & 85 & 91 \\
\hline & EUp- & 42 & 72 & 39 & 73 & 101 & 93 & 61 & 91 & 70 & 88 \\
\hline
\end{tabular}

BS = baseline scenario

EUe $=$ quasy equal treatment scenario

EUp $=$ EU negotiating proposal scenario

EU. $+=$ accession scenario of competitive processing industry

EU.- = accession scenario of non-competitive processing industry

In the sectors under investigation, Slovenia will not switch from a net importer to a net exporter or vice versa (the only probable exception is beef, Table 6). However, important deviations caused by the EU accession will occur predominantly in wheat and the whole livestock production (higher imports; the only exemption could be beef). Due to long-term trends of (producer) price reduction, it is expected that Slovenia will become a net importer of poultry before the EU accession regardless of the scenario un- der consideration (also BS). Milk and dairy products' surpluses should decrease considerably.

\section{Agricultural income}

The results of the policies under the optimistic EUe+ scenario point to a slight or even significant improvement in the income situation of many sectors, including that of dairy farmers and sugar beet producers (Table 7), when expressed 
Vol. 12 (2003): 3-19.

Table 7. Likely agricultural income situation (in EUR ha' or head $^{1}$ ) and percentage rate of production rentability.

\begin{tabular}{|c|c|c|c|c|c|c|c|c|c|c|}
\hline & Wheat & Maize & Barley & $\begin{array}{c}\text { Sugar } \\
\text { beet }\end{array}$ & Milk & Beef & Pork & Poultry & Eggs & $\begin{array}{r}\text { Sheep } \\
\text { meat }\end{array}$ \\
\hline \multicolumn{11}{|l|}{ Income } \\
\hline $\mathrm{BS}$ & 339 & -42 & 132 & 172 & 1,088 & 137 & 221 & 25 & 178 & 491 \\
\hline $\mathrm{EUe}+$ & 366 & 358 & 284 & 333 & 1,100 & 408 & 220 & -24 & -5 & 731 \\
\hline EUe- & 319 & 341 & 280 & 238 & 889 & 378 & 145 & -192 & -282 & 782 \\
\hline EUp+ & 281 & 15 & 107 & 292 & 1,049 & 172 & 184 & -31 & -19 & 493 \\
\hline EUp- & 208 & -25 & 90 & 202 & 848 & 149 & 114 & -198 & -292 & 461 \\
\hline \multicolumn{11}{|c|}{ Rentability of production } \\
\hline BS & 111 & 76 & 86 & 74 & 110 & 82 & 87 & 95 & 94 & 84 \\
\hline $\mathrm{EUe}+$ & 114 & 106 & 105 & 81 & 111 & 110 & 87 & 91 & 82 & 103 \\
\hline EUe- & 109 & 104 & 104 & 76 & 99 & 107 & 80 & 79 & 62 & 107 \\
\hline EUp+ & 105 & 80 & 84 & 79 & 108 & 85 & 84 & 91 & 81 & 84 \\
\hline EUp- & 97 & 77 & 82 & 75 & 96 & 82 & 78 & 79 & 61 & 82 \\
\hline
\end{tabular}

110 pigs or sheep, 10,000 chickens or 100 layers.

$\mathrm{BS}=$ baseline scenario

EUe $=$ quasy equal treatment scenario

EUp $=$ EU negotiating proposal scenario

EU. $+=$ accession scenario of competitive processing industry

EU.- = accession scenario of non-competitive processing industry

Table 8. Sector and aggregate agricultural income forecast $(\mathrm{BS}=100)$.

\begin{tabular}{lrrrrrrrrrrr}
\hline & Wheat & Maize* & Barley & $\begin{array}{c}\text { Sugar } \\
\text { beet }\end{array}$ & Milk & Beef & Pork & Poultry & Eggs & $\begin{array}{r}\text { Sheep } \\
\text { meat }\end{array}$ & $\begin{array}{r}\text { Aggregate } \\
\text { EUe+ }\end{array}$ \\
\hline 104 & -920 & 223 & 204 & 99 & 340 & 96 & -93 & -3 & 150 & 129 \\
EUe- & 87 & -871 & 219 & 142 & 74 & 312 & 61 & -706 & -123 & 163 & 105 \\
EUp+ & 78 & -36 & 79 & 179 & 83 & 127 & 81 & -123 & -10 & 96 & 87 \\
EUp- & 55 & 60 & 66 & 121 & 67 & 109 & 48 & -732 & -128 & 88 & 64 \\
\hline
\end{tabular}

*Note: BS income is negative (with low absolute value), therefore EUe. would bring significant improvements.

BS = baseline scenario

EUe = quasy equal treatment scenario

$\mathrm{EUp}=\mathrm{EU}$ negotiating proposal scenario

EU. $+=$ accession scenario of competitive processing industry

EU.- = accession scenario of non-competitive processing industry

per unit of production. But the projection is the opposite in the case of more likely EUp scenario. This deterioration is even much higher, when taking into account production quotas in calculation of sector income (Table 8).

A significant improvement, but conditioned upon direct payments, is expected only in currently discriminated coarse grains and beef pro- duction. Situation is expected to be the worst in poultry and egg sectors. In the case of non-competitive food processing industry, a rapid stagnation of intensive livestock production is expected.

In the case of realisation of the current Commission proposal, farmers' incomes at the aggregate level will significantly decrease in compar- 
Kavcic, S. et al. EU enlargement and the Common Agricultural Policy

ison with the baseline scenario. Should direct payments as assumed under EUe be granted and prices of commodities remain relatively high (EU+ scenario), the income situation will be significantly improved, which is projected also in European Commission projection (European Commission 2002b). On the contrary, it will decline dramatically with the proposed starting level of direct payments ( $25 \%+$ top ups) and without a significant increase (to the EU average level) of competitiveness of the domestic food industry. The difference between the quasi equal treatment accession scenario (EUe+) and the baseline one is very significant - approximately $29 \%$, but deterioration under more realistic $\mathrm{EUp}+$ is around $13 \%$, and under also highly probable EUp-even $36 \%$. The situation to be expected if nothing crucial happens by the end of accession negotiations is somewhere between $\mathrm{EUp}+$ and EUp-, therefore the income reduction in the rank of a quarter.

These results show the sensitivity of accession conditions. The accession with relatively low level of direct and structural payments and considering low competitiveness of the food industry is far from being attractive for Slovenian producers. The general picture is even the opposite to the one that can be expected taking into account several general conclusions about EU enlargement effects. In the case of no eligibility for the whole amount (equal treatment as current member states) of direct payments, accession means a reduction of total agricultural income with enormous deterioration within some sectors (industrial livestock production, wheat and milk), and improvement only in currently discriminated sectors (maize and beef).

\section{Discussion and conclusions}

The paper deals with likely effects of changed economic relations anticipated by different price levels and budgetary support on supply response, cost competitiveness of production and farm in- comes in Slovenian agriculture after the EU accession. The major part of studies on the accession effects (e.g. Banse 2000, Münch 2000, European Commission 2002a) concludes that immediate adoption of the total CAP will increase production and agricultural incomes in the new member states including Slovenia. Therefore, transition period for direct payments should be justified to prevent their negative impact on restructuring (Pouliquen 2001, European Commission 2002b). The thesis examined in the paper is that those expectations and uniform solutions could lead to significant deterioration of economic situation in Slovenian agriculture due to distinctive economic, structural and natural conditions as well as differences in the pre-accession agricultural policies. The results obtained indicate that accession under any of presented scenarios would not increase agricultural production in Slovenia. Due to mainly low supply response assumed in the model (Stoforos et al. 2000) market effects are smaller in comparison with some previous estimates for Slovenian agriculture (e. g. Münch 2000). This could be supported by low factor mobility in Slovene agriculture. It is conditioned by small and dispersed farm structure with average farm size of 5 ha UAA, over-aged and less educated farm holders (low labour opportunity cost), high land prices due to owners' speculations and expectations, relatively high capital costs as well as conservative farmers' values and beliefs, resulting in important share of part time and subsistence farming.

The results also confirm the hypothesis that inevitable alteration of trade flows will take place due to the changed economic conditions at the time of accession. However, variations of price levels and budget support can be found. A part of changes will also occur as a result of different food-processing industry's competitiveness. Authors expect that in the case of Slovenia, changes affected by low competitiveness could even be greater than presented in the analysis.

Wider interest is anticipated, above all, for estimates of income situation in Slovenian agriculture after the accession to the EU. Compared 
Vol. 12 (2003): 3-19.

with the baseline, only under the less realistic conditions of the optimistic accession scenario income situation could be improved in some sectors. This might be the case for coarse grains, sugar beet and beef sectors, but this improvement should not bring any enthusiasm concerning the perspectives of these sectors as competitiveness and actual income situation remain low. Nevertheless, accession is not as attractive for Slovenian farm producers as one would expect - the case can be even opposite unless producers receive full direct payments. Even under the optimistic scenario, total agricultural income will increase only slightly, with significant worsening of income situation in some sectors (pork and poultry).

The model results reveal the inappropriateness of the horizontal approach for all candidate countries. Without the differentiation among the candidates, enlargement cannot be economically and socially impartial. The culmination of accession negotiations is expected to take place at the end of year 2002. The Slovenian representatives expect from the EU to apply fully the principle of differentiation as a condition for efficient integration of all ten candidate countries, the argument that might be supported with the results from the paper.

During the pre-accession period, all the efforts have to be made to strengthen the arguments for realisation of direct payments. Especially important is also the institutional development with establishment of paying agency and reestablishment of comparable mechanisms proposed by the agricultural policy reform. Some other steps of adjustment also need to be considered. Candidate countries should not neglect structural and environmental policies on the account of economically and politically questionable direct payments (Buckwell et al. 1997, Kola 1998, Rabinowicz 1999).

Although direct payments have political and economical relevance, in the long run improvement of competitiveness is essential for Slovenian agriculture and down-stream industry. This can be achieved efficiently also by measures such as faster trade liberalisation, support for factor mobility, more targeted budgetary policy in terms of externalities and above all, with a clear description of the actual and projected situation for domestic producers. Also dynamic technical and structural development could and should play an important role in the near future and have to be supported by all means at disposal of agricultural policy. Nevertheless, individual producer with more entrepreneur skills will play the major role in time to come along with decreasing rate of policy influence. However, due to generally unfavourable socio-economic characteristics in the sector, dynamics of necessary changes in Slovenia is expected to be very low.

Acknowledgements. Authors would like to thank Miroslav Rednak and Tina Volk for their valuable comments during model development and for assistance and provision of data. This research was undertaken with support from the European Commission's ACE Phare Program and National Research Foundation.

\section{References}

Baldwin, R., Francois, J.F. \& Portes, R. 1997. The costs and benefits of eastern enlargement: the impact on the EU and Central Europe. Economic Policy 24: 125176.

Banse, M. 2000. Macroeconomic implications of EU accession. In: Tangermann, S. \& Banse, M. (eds.). Central and Eastern European agriculture in an expanding European Union. Wallingford, CAB International. p. 133-155.
Bauer, S. 1989. Historical review, experiences and perspectives in sector modelling. V: Agricultural sector modelling. Proceedings of the 16th symposium of the European association of agricultural economists, Bonn, 14-15 April 1988. Kiel, Wissenschaftsverlag Vauk, p. 3-22.

Bojnec, S. \& Swinnen, J. 1997. The pattern of agricultural price distortion in Central and Eastern Europe. Food Policy 22: 289-306. 
Kavcic, S. et al. EU enlargement and the Common Agricultural Policy

Buckwell, A., Blom, J., Commins, P., Hervieu, B., Hofreither, M., Meyer, H. von, Rabinowicz, E., Sotte, F. \& Sumpsi Vinas, J.M. 1997. Towards a common agricultural and rural policy for Europe. Brussels, European Commission. $130 \mathrm{p}$.

Burrell, A. 1995. Design and performance of agricultural sector models. V: Agricultural sector modelling. Luxembourg, Office for official publications of the European communities. p. 5-25.

Erjavec, E., Gambelli, D. \& Turk, J. 1998b. Food demand in Slovenia. Lebensmittelsnachfrage in Slowenien. Bodenkultur 49, 4: 273-279.

Erjavec, E., Rednak, M. \& Volk, T. 1998a. The European Union enlargement - the case of agriculture in Slovenia. Food Policy 23: 395-409.

Erjavec, E. \& Turk, J. 1997. Supply elasticities in Slovene agriculture. Zbornik Biotehniške fakultete Univerze v Ljubljani, Kmetijstvo, Zootehnika 70: 85-98.

European Commission 1995. Agricultural situation and prospects in the Central and Eastern European countries: Slovenia. Working document, European Commission DG VI, Brussels. $47 \mathrm{p}$.

European Commission 1998. Agricultural situation and prospects in the Central and Eastern European countries: Slovenia. Working document, European Commission DG VI, Brussels. 74 p.

European Commission 2002a. Analysis of the impact on agricultural markets and incomes of EU enlargement to the CEECs. European Commission, DG for agriculture, Brussels. 89 p.

European Commission 2002b. Enlargement and agriculture: Successfully integrating the new member states into the CAP. Issues paper + annex. European Commission, Brussels. 23 p. +54 p.

FAPRI 2001. FAPRI 2001 US and world agricultural outlook. Food and Agricultural Policy Research Institute. Staff Report 1-01. Iowa State University and the University of Missouri-Columbia. 403 p. ISSN 1534-4533

Frohberg, K. 1999. IAMO model for Slovenia and Bulgaria. In: ACE-Phare workshop "Analysing agricultural policy options under transition in view of future accession to EU", Domzale, 8-9 March 1999. 6 p.

Gardiner, H.W., Roningen, V.O. \& Liu, K. 1989. Elasticities in the trade liberalisation database. USDA, Agriculture and trade analysis division. Economic research service, Staff report No. AGES 89-20. 24 p.

Goldman, R.H., Grodzins, C. \& Mann, C. 1991. Economic analysis of agricultural policies: $A$ basic training manual with special reference to price analysis. Rome, Harvard Institute for International Development and FAO. $172 \mathrm{p}$.

Golez, M. 2001. Modelne kalkulacije 2000. Poljedelstvo. (Model calculations for 2000. Arable farming.) Prikazi in informacije 219. Ljubljana, Kmetijski institut Slovenije. $51 \mathrm{p}$.

Gorton, M. \& Davidova, S. 2000. The international competitiveness of CEEC agriculture. Idara working paper series, Work Package 5, Working Paper 2/1. Wye, Wye college, University of London. $24 \mathrm{p}$.

Harrigan, J., Loader, R. \& Thirtle, C. 1992. Agricultural price policy: Government and the market. Rome, FAO. $281 \mathrm{p}$.
Kavcic, S. 2000. Ocena ekonomskih ucinkov moznih agrarnopoliticnih razmer $v$ slovenskem kmetijstvu (Estimation of economic effects of possible agricultural policy options in Slovenian agriculture). PhD thesis. Domzale, University of Ljubljana. 172 p. (in Slovenian).

Khan, N.P. 1997. Comparative advantage of United States agriculture and effects of policies on agricultural development and trade: Policy Analysis Matrix approach. PhD Thesis. Kentucky, University of Kentucky. $172 \mathrm{p}$.

Kola, J. 1998. Reforms of the Common agricultural policy and agriculture in Finland. Agricultural and Food Science in Finland 7: 181-196.

Kydd, J., Pearce, R. \& Stockbridge, M. 1997. The economic analysis of commodity systems: Extending the policy analysis matrix to account for environmental effects and transaction costs. Agricultural Systems 55, 2: 323-345.

Mergos, G.J. 1988. APSS: Agricultural policy spreadsheet simulator - A programme for training in agricultural policy analysis. FAO / ESP / training division. Rome, FAO. 58 p.

Mergos, G.J., Karadeloglou, P. \& Stoforos, C.E. 1999. Exploring agricultural price and trade policy reform under transition in Albania. Economics of Planning 32: 103-127.

Michalek, J. 1995. An application of the Policy Analysis Matrix for an evaluation of agricultural policies in the Slovak Republic. Oxford Agrarian Studies 23, 2: 177196.

Monke, E.A. \& Pearson, S.R. 1989. The Policy Analysis Matrix for agricultural development. Ithaca, Cornell University. $279 \mathrm{p}$.

Münch, W. 2000. Effects of CEEC-EU accession on agricultural markets in the CEEC and on government expenditure. In: Tangerman, S. \& Banse, M. (eds.). Central and Eastern European agriculture in an expanding European Union. Wallingford, CAB International. p. 113-132.

OECD 2001a. Review of agricultural policy, country report: Slovenia. Paris, Organisation for Economic Cooperation and Development (OECD). $184 \mathrm{p}$.

OECD 2001b. OECD agricultural outlook 2001-2006. Paris, Organisation for Economic Cooperation and Development (OECD). $189 \mathrm{p}$.

Pearson, S., Monke, E., Argwings-Kodhek, G., Avillez, F., Mukumbu, M., Pagiola, S., Sellen, D. \& Winter-Nelson, A. 1995. Agricultural policy in Kenya: Application of the Policy Analysis Matrix. Ithaca, Cornell University. $300 \mathrm{p}$.

Pearson, S.R., Avillez, F., Bentley, J.W., Finan, T.J., Fox, R., Josling, T., Langworthy, M., Monke, E. \& Tangerman, S. 1987. Portuguese agriculture in transition. Ithaca, Cornell University. 283 p.

Pouliquen, A. 2001. Competitiveness and farm incomes in the CEEC agri-food sectors. Implications before and after accession for EU market and policies. Working document. European Commission, Brussels. 26 p.

Rabinowicz, E. 1999. Redesigning the CAP to meet challenges of EU enlargement and the WTO: what can agricultural economic research contribute. Eu- 
Vol. 12 (2003): 3-19.

ropean Review of Agricultural Economics 26, 3: 265281.

Salvatici, L., Anania, G., Arfini, F., Conforti, P., De Muro, P., Londero, P. \& Sckokai, P. 2000. Recent development in modelling the CAP: hype or hope? In: Heckelei, T. et al. (eds.). Proceedings of 65th EAAE seminar "Agricultural sector modelling and policy information systems", Bonn, 29-31 March 2000. Kiel, Wissenschaftsverlag Vauk, p. 8-26.

Stoforos, E.C. 1997. Agricultural sector modelling for policy analysis: The case of Greece. PhD Thesis. Reading, University of Reading. 132 p.

Stoforos, C., Kavcic, S., Erjavec, E. \& Mergos G. 2000. Agricultural policy analysis model for Slovenian agriculture. In: Giannias, S. \& Mergos, G. (eds.). Selective readings on economies in transition. Cahier Options Mediterraneennes 44: 91-102.

Tongeren, F.W. van, Meijl, H. van, Veenendaal, P., Frandsen, S., Nielsen, C.P., Staehr, M., Brockmeier, M., Manegold, D., Francois, J., Rambout, M., Surry, Y., Vaittinen, R., Kerkela, L., Raitinger, T., Thomson, K., De Frahan, B.H., Mekki, A.A.E. \& Salvatici, L. 2000.
Review of agricultural trade models: an assessment of models with EU policy relevance. In: Heckelei, T. et al. (eds.). Proceedings of 65th EAAE seminar "Agricultural sector modelling and policy information systems", Bonn, 29-31 March 2000. Kiel, Wissenschaftsverlag Vauk, p. 23-43.

Volk, T. 2001a. Modelne kalkulacije 2000. Zivinoreja. (Model calculations for 2000. Animal farming.) Prikazi in informacije 218. Ljubljana, Kmetijski institut Slovenije. 81 p. (in Slovenian).

Volk, T. 2001b. Modelne kalkulacije 2000. Domaca krma. (Model calculations for 2000. Feed.) Prikazi in informacije 221. Ljubljana, Kmetijski institut Slovenije. 35 p. (in Slovenian).

Yao, S.J. 1997a. Comparative advantages and crop diversification: A Policy Analysis Matrix for Thai Agriculture. Journal of Agricultural Economics 48, 2: 211222.

Yao, S.J. 1997b. Comparative advantage in agriculture, forestry and fishery under economic transition in Estonia. Discussion papers. Portsmouth, University of Portsmouth, Department of Economics. $91 \mathrm{p}$. 